\title{
PERBEDAAN KEMAMPUAN BERPIKIR DIVERGEN MENGGUNAKAN MODEL PEMBELAJARAN LEARNING CYCLE 5 E BERBASIS BRAISTORMING DAN CONVENTIONAL TEACHING PADA SPEAKING CLASS PADA SISWA SEKOLAH MENENGAH ATAS (SMA) KABUPATEN SITUBONDO
}

\author{
Dian Maya Kurnia \\ aroundmaya86@gmail.com \\ Fakultas Sastra, Universitas Abdurachman Saleh Situbondo
}

\begin{abstract}
Abstrak
Penelitian ini bertujuan untuk mengetahui perbedaan kemampuan berpikir divergen bahasa Indonesia antara kelompok siswa yang mengikuti pembelajaran dengan menggunakan model pembelajaran learning cycle $5 E$ berbasis brainstorming dan kelompok siswa yang mengikuti pembelajaran dengan menggunakan model pembelajaran konvensional. Penelitian ini merupakan penelitian eksperimen semu (quasi experiment) dengan rancangan post-test only control group design. Populasi penelitian ini adalah seluruh siswa kelas XI di SMA Kecamatan Mangaran Kabupaten Situbondo yang berjumlah yang berjumlah 200 orang. Sampel penelitian ini yaitu siswa kelas XI IPA 1 MA Nurush Sholeh yang berjumlah 22 orang dan siswa kelas XI IPA 1 MA Miskyatul Ulum yang berjumlah 22 orang. Pada kelas eksperimen diterapkan model pembelajaran learning cycle $5 e$ berbasis brainstorming dan pada kelas kontrol diterapkan model pembelajaran konvensional. berdasarkan perhitungan uji hipotesis yang mengacu pada ketentuan pengambilan keputusan uji hipotesis, dikatakan bahwa Ho ditolak dan Ha diterima. Jadi dapat disimpulkan bahwa terdapat perbedaan yang signifikan kemampuan divergen antara siswa yang mengikuti pembelajaran dengan model pembelajaran Learning Cycle dengan siswa yang mengikuti pembelajaran yang menggunakan model pembelajaran Konvensional pada siswa kelas XI MA Nhurush Sholeh dan MA Miskyatul Ulum Kecamatan Mangaran Situbondo tahun pelajaran 2017/2018 dengan $\mathrm{T}_{\text {hitung }}>\mathrm{T}_{\text {tabel }}$ yaitu $6,67>2,02$ pada taraf siginifikan $\alpha(0,05)$.
\end{abstract}

Kata kunci: learning cycle $5 e$ berbasis brainstorming, dan kemampuan berpikir divergen

\section{PENDAHULUAN}

Pendidikan dipandang sangat penting untuk mempersiapkan masa depan yang lebih baik. Perubahan zaman yang dilalui dengan persaingan yang ketat menuntut manusia untuk mempunyai kesiapan yang tinggi, sehingga apapun yang dihadapi dapat dilaksanakan tanpa adanya keragu-raguan. Sejalan dengan hal di atas, mengenai isi Undang-Undang Nomor 20 Tahun 2003 Bab II Pasal 3 tentang fungsi pendidikan nasional adalah untuk dikembangkannya kemampuan dan membentuk watak serta peradaban bangsa yang bermartabat dalam rangka 
mencerdaskan kehidupan bangsa, bertujuan untuk berkembangnya potensi peserta didik agar menjadi manusia yang beriman dan bertakwa kepada Tuhan Yang Maha Esa, berakhlak mulia, sehat, berilmu, cakap, kreatif, mandiri, dan menjadi warga negara yang demokratis serta bertanggung jawab. Sehingga dalam prosesnya haruslah dilakukan perubahan.

Perubahan yang dapat dilakukan secara nyata adalah, perubahan dalam proses pembelajaran yang dilakukan di sekolah. Selama ini, bila dalam prosesnya belajar di $\mathrm{d}$ alam ruang kelas senantiasa guru yang berperan aktif, maka dilakukan perubahan menjadi siswa yang sangat berperan aktif (student centered). Dengan diupayakannya peran siswa dalam proses pembelajaran, maka akan meningkatkan pola pikir siswa. Hal ini didukung oleh pernyataan Degeng (dalam Riyanto, 2008:5) "bahwa proses pembelajaran merupakan pengaitan pengetahuan baru pada struktur kognitif yang sudah dimiliki siswa". Jadi dalam hal ini memiliki arti bahwa dalam proses belajar, siswa akan menghubungkan pengetahuan baru. Dengan kata lain belajar dapat menjadi keterampilan persepsi dan kemampuan berpikir.

Salah satu kemampuan berpikir yang dapat dikembangkan pada siswa di sekolah menengah umum adalah kemampuan berpikir divergen. Berpikir divergen dapat dikembangkan untuk mengasah kreativitas siswa. Seperti halnya yang diungkapkan oleh Liliasari (2003) " setiap insan di dunia harus dibekali suatu keterampilan berpikir yang lebih tinggi, yaitu keterampilan berpikir divergen. Sehingga prioritas utama pendidikan adalah bagaimana mendidik siswa, khususnya siswa sekolah menngah umum tentang bagaimana meningkatkan kemampuan berpikir divergen.

Di setiap sekolah menengah umum diwajibkan adanya matapelajaran Bahasa Inggris. Matapelajaran Bahasa Inggris merupakan salah satu matapelajaran yang mampu mengembangkan kemampuan berpikir divergen pada siswa. Hal tersebut didukung oleh pernyataan Ngalim ( 1997:8) " kekuatan dan kemajuan Indonesia di masa depan sangat tergantung pada kreativitas dari sumber daya manusia. Pelajaran bahasa salah satunya pembelajaran Bahasa Inggris adalah 
matapelajaran yang paling besar sentuhannya dalam meningkatkan kemampuan berpikir divergen.

Salah satu tujuan umum pengajaran Bahasa Inggris adalah siswa memiliki kemampuan menggunakan bahasa Inggris untuk meningkatkan kemampuan intelektual Ngalim (1997:5). Kemampuan intelektual yang dimaksud adalah mampu berpikir divergen, menggunakan akal sehat, menerapkan pengetahuan yang berguna dan memecahkan masalah.

Berpikir adalah eksplorasi pengalaman yang dilakukan secara sadar dalam mencapai suatu tujuan (deBono, dalam Sugiarti, 2012: 46). Tujuan itu berbentuk pemahaman, pengambilan keputusan, perencanaan, pemecahan masalah, tindakan dan penilaian. Keterampilan berpikir dapat dikelompokkan menjadi keterampilan berpikir dasar dan keterampilan berpikir kompleks. Keterampilan berpikir kompleks dikenal sebagai keterampilan berpikir kritis dan kemampuan berpikir kreatif. Berpikir kreatif menggunakan dasar pengembangan dan penemuan ide yang asli, estetis, dankonstruktif yang menekankan pada berpikir intuitif untuk memunculkan perspektif asli pemikir (Costa, dalam Sugiarti, 2012: 44) Selain itu Guilford berpendapat bahwa ada lima komponen pokok dalam berpikir yaitu: 1) kognisi, berarti penemuan atau penemuan kembali, 2) mengingat, berarti menyimpan apa yang telah dikenal, 3) berpikir konvergen, berarti berpikir maju satu arah yang benar atau satu jawaban yang paling tepat atau pemecahan satu dari suatu masalah, 4) berpikir divergen, berarti berpikir dalam arah yang berbedabeda, akan diperoleh jawaban-jawaban unik yang berbeda-beda tapi benar. Istilah lain dari berpikir divergen ialah berpikir kreatif (creative thingking), berpikir imajiner (imaginative thingking), berpikir asli (original). Salah satu ciri dari anak yang kreatif atau mampu berpikir divergen adalah menanggapi pertanyaan yang diajukan serta cenderung memberi jawaban lebih banyak, 5) evaluasi, berarti keputusan mengenai kebaikan, kebenaran atau kesesuaian apa yang kita ketahui, kita ingat, dan apa yang kita hasilkan dalam berpikir (Slameto, 2010: 144).

Dalam teori konstruktivistik, proses pembelajaran bahasa Indonesia disikapi sebagai kreativitas dalam menata serta menghubungkan pengalaman dan 
pengetahuan sehingga membentuk suatu keutuhan. Dalam tindak kreatif tersebut siswa pada dasarnya merupakan subjek pemberi makna. Dalam proses pembelajaran, sebaiknya guru tidak menggurui melainkan secara adaptif berusaha memahami jalan pikiran siswa untuk kemudian menampilkan sejumlah kemungkinan sehingga siswa diajak berpikir divergen.

Kenyataannya, berdasarkan hasil observasi dibeberapa sekolah dasar di daerah buleleng sampai saat ini kemampuan berpikir divergen di tingkat sekolah dasar belum ditangani dengan baik. Dalam pengajaran bahasa Indonesia di sekolah dasar, siswa belum dibiasakan untuk melihat masalah dari berbagai sudut pandang atau kurang diberikan kesempatan untuk memberikan berbagai jawaban dari suatu masalah. Siswa sering diberikan pelajaran dalam bentuk ceramah dan tanya jawab, sehingga kesempatan kemampuan berpikir siswa sulit dikembangkan. Hal tersebut mengakibatkan siswa kurang toleran dan kurang terbuka terhadap pendapat yang divergen atau menyimpang dari biasanya.

Berdasarkan hasil observasi yang telah dilakukan pada bulan Desember 2016, di sekolah menengah umum yang termasuk Kecamatan Asembagus ditemukan bahwa selama ini guru dalam mengajar mata pelajaran bahasa Inggris hanya menggunakan metode ceramah kemudian siswa diberikan latihan soal. Selain itu, dalam pembelajaran, guru hanya sebatas memberikan materi dan memecahkan masalah langsung menuju jawaban benar tanpa memberikan kesempatam kepada siswa untuk menemukan jawaban atau alternatif lain. Oleh karena, dapat dikatakan bahwa guru dalam melakukan proses pembelajaran masih cenderung menerapkan metode konvensional. Siswa diposisikan sebagai objek dalam pembelajaran. Siswa kurang dilatih untuk mengembangkan pemikiran awal yang telah mereka peroleh dari lingkungannya. Pemahaman siswa hanya sebatas pada apa yang mereka dengar, dan mereka ingat.

Semakin seringnya pembelajaran bersifat teacher center akan dihasilkan kualitas pembelajaran yang rendah. Hal ini didukung oleh pendapat Sanjaya (2006) bahwa rendahnya kualitas pendidikan jika dilihat dari sisi proses adalah adanya anggapan bahwa selama ini proses pendidikan yang dibangun oleh guru 
cenderung terbatas pada penguasaan materi pelajaran atau bertumpu pada pengembangan aspek kognitif tingkat rendah yang tidak mampu mengembangkan kreatifitas berpikir atau proses belajar mengajar dianggap cenderung menempatkan siswa sebagai objek yang harus diisi dengan berbagai bahan-bahan hafalan.

Di sisi lain terdapat model pembelajaran dapat untuk meningkatkan kemampuan berpikir divergen siswa pada mata pelajaran Bahasa Inggris salah satunya model pembelajaran learning cycle 5e. Model siklus belajar merupakan salah satu model pembelajaran yang menerapkan teori belajar konstruktivisme (Adnyana, 2011). Pembelajaran siklus ini pertama kali diperkenalkan oleh Robert Ksrplus (Wena, 2008). Sesuai dengan namanya model pembelajaran learning cycle 5e ini memiliki 5 tahap diantaranya 1) tahap engagement (pembengkitan minat) merupakan tahap awal, pada tahap ini guru berusaha membangkitkan minat dan keinginan siswa tentang apa yang akan diajarkan. 2) tahap eksploration pada tahap ini dibentuk suatu kelompok belajar, kemudian diberi kesempatan bekerja sama dalam kelompoknya. 3) tahap explanation (tahap penjelasan) pada tahap ini guru dituntut mendororng siswa untuk menjelaskan suatu konsep dengan kalimat atau pemikiran sendiri, meminta bukti dan klarifikasi atas penjelasan siswa. Siswa dalam hal ini berpartisipasi secara mental dan sosial. 4) Tahap elaboration (tahap elaborasi) pada tahap ini, guru memberikan situasi baru atau masalah baru. Dengan demikian siswa dengan aktif memberikan solusi berdasarkan informasi yang telah mereka miliki dari tahap-tahap siklus sebelumnya. 5) evaluation. Pada tahap evaluasi, guru dapat mengamati pengetahuan atau pemahaman siswa dalam menerapkan konsep baru. Siswa dapat melakukan evaluasi diri dengan mengajukan pertanyaan terbuka dan mencari jawaban yang menggunakan observasi, bukti, dan penjelasan yang diperoleh sebelumnya.

Rumusan masalah penelitian ini adalah apakah terdapat perbedaan kemampuan berpikir divergen menggunakan learning cycle $5 e$ berbasis 
braistorming dan conventional teaching pada siswa Sekolah Menengah atas di Kabupaten Situbondo?

\section{METODE PENELITIAN}

Penelitian ini menggunakan pendekatan kuantitatif dan metode penelitian yang digunakan adalah metode quasi eksperimen. Metode ini digunakan untuk mengetahui perbedaan keaktifan siswa menggunakan model pembelajaran Learning Cycle dengan model pembelajaran Conventional Teaching pada speaking class pelajaran Bahasa Inggris. Pada penelitian ini dikelompokkan menjadi dua kelompok yaitu kelompok eksperimen dan kelompok kontrol. Kelompok eksperimen yaitu kelompok siswa yang diberikan perlakuan dengan menggunakan model pembelajaran Learning Cycle dan kelompok kontrol yaitu siswa yang diberikan perlakuan dengan menggunakan model pembelajaran Conventional Teaching yang akan dilihat hasilnya adalah keaktifan siswa setelah peneliti menerapkan model model pembelajaran Learning Cycle dan model pembelajaran Conventioanl Teaching.

Tabel 1. Rancangan Desain Penelitian

\begin{tabular}{lll}
\hline \multicolumn{1}{c}{ Kelas } & \multicolumn{1}{c}{ Model Pembelajaran } & \multicolumn{1}{c}{ Postes } \\
\hline XI IPA MA Nurus Sholeh & Learning Cycle & Eksperimen \\
XI IPA MA Miskyatul Ulum & Conventional Teaching & Kontrol \\
\hline
\end{tabular}

Populasi dalam penelitian ini adalah seluruh siswa SMA se Kecamatan Mangaran Kabupaten Situbondo pada Tahun Pelajaran 2017-2018. Sampel dalam penelitian ini adalah siswa kelas XI MA Nurush Sholeh yang terdiri dari 22 siswa sebagai eksperimen dan MA Miskyatul Ulum yang terdiri dari 22 siswa sebagai kontrol dengan teknik uji homogen varian atau disebut dengan sampel kelompok. Pada uji homogen varian siswa telah terkumpul dalam sebuah kelas. 
Pengambilan sampel dilakukan dengan mengambil seluruh siswa dikelas tertentu sebagai sampel penelitian.

\section{Data dianalisis dengan uji normalitas sebaran data dan Uji Homogenitas} Varians.

Untuk mengetahui perbedaan antara model pembelajaran Learning Cycle dengan model pembelajaran Conventional Teaching terhadap speaking class dapat menggunakan rumus Polled Varians yaitu sebagai berikut:

$$
\mathrm{t}=\frac{\overline{\mathrm{X}}_{1}-\overline{\mathrm{X}}_{2}}{\sqrt{\frac{\left(\mathrm{n}_{1}-1\right) \mathrm{s}_{1}{ }^{2}+\left(\mathrm{n}_{2}-1\right) \mathrm{s}_{2}^{2}}{\mathrm{n}_{1}+\mathrm{n}_{2}-2}\left(\frac{1}{n}+\frac{1}{n}\right)}}
$$

Keterangan:

$\mathrm{X} 1$ : rerata skor post test kelompok eksperimen

$\mathrm{X} 2$ : rerata skor post test kelompok kontrol

$\mathrm{S}^{2} \quad$ : varians skor post test kelompok eksperimen

S22 : varians skor post test kelompok kontrol

n1 : jumlah siswa kelas eksperimen

n2 : jumlah siswa kelas kontrol

Kriteria pengujian adalah sebagai berikut (tabel distribusi t):

1) Jika $\mathrm{n} 1=\mathrm{n} 2$ dan varians homogen, dapat digunakan salah satu rumus tersebut, dengan $\mathrm{db}=\mathrm{n} 1+\mathrm{n} 2-2$.

2) Jika $n_{1} \neq n_{2}$ dan varians homogen, digunakan rumus Polled Varians; dengan $d b$ $=\mathrm{n}_{1}+\mathrm{n}_{2}-2$.

3) Jika $n_{1}=n_{2}$ dan tidak homogen, dapat digunakan salah satu rumus di atas; dengan $\mathrm{db}=\mathrm{n}_{1}-1$ atau $\mathrm{n}_{2}-1$ (bukan $\left.\mathrm{n}_{1}+\mathrm{n}_{2}-2\right)$. 
4) Jika $\mathrm{n}_{1 \neq} \mathrm{n}_{2}$ dan tidak homogen, digunakan rumus Separated Varians, harga $\mathrm{t}$ pengganti t tabel dihitung selisih dari harga t tabel; dengan $\mathrm{db}=\left(\mathrm{n}_{1}-1\right) \mathrm{dan} \mathrm{db}$ $=\left(\mathrm{n}_{2}-1\right)$, dibagi dua, kemudian ditambah dengan harga $\mathrm{t}$ yang terkecil.

5) Kriteria pengujian $\mathrm{H}_{0}$ ditolak jika $t_{\text {hitung }}>t_{\text {tabel }}$, dengan taraf signifikansi $5 \%$ Sebelum analisis statistik dilakukan, terlebih dahulu dilakukan uji normalitas data dan uji homogenitas. Uji normalitas menggunakan Uji Lilliefors dan uji homegenitas menggunakan uji Varians. Kedua uji ini dilakukan sebgai syarat dari analisis data.

\section{HASIL PENELITIAN DAN PEMBAHASAN}

\section{Pengujian Hipotesis}

Dari data penelitian didapat rata-rata hasil belajar kelompok eksperimen siswa yang diajarkan dengan model pembelajaran Learning Cycle adalah 81,16 dan simpangan baku (stndar deviasi) yaitu 100,9. Untuk harga rata-rata hasil belajar kelompok kontrol siswa yang diajarkan dengan model pembelajaran Konvensional adalah 62,0 dan simpangan baku (standar deviasi) 99,2 , untuk mengetahui apakah perbedaan kedua nilai rata-rata tersebut signifikan (bermakna), maka perlu dilakukan analisis lebih lanjut dengan analisis uji statistik menggunakan uji-t. Rumus yang digunakan adalah pollend varians yaitu:

$$
\begin{aligned}
& t=\frac{\bar{x}_{i}-\bar{x}_{2}}{\sqrt{\frac{S_{1}^{2}}{n}+\frac{S_{2}^{2}}{n}}} \\
& t=\frac{81,16-62,0}{\sqrt{\frac{100,9}{22}+\frac{99,2}{22}}} \\
& t=\frac{19,16}{\sqrt{4,58+4,5}} \\
& t=\frac{19,16}{\sqrt{9,08}} \\
& t=\frac{19,16}{3,01} \\
& t=6,36 \\
& t_{\text {tabel }}=\left(\mathrm{n}_{1}+\mathrm{n}_{2}\right)-2=(22+22)-2=42 \\
& \quad(\alpha=0,05, \mathrm{n}=42)=\mathbf{2 , 0 2}
\end{aligned}
$$


Dari hasil perhitungan uji-t dengan menggunakan t-tes diperoleh $\mathrm{T}_{\text {hitung }}=$ 6,36 serta $T_{\text {tabel }}$ (pada taraf signifikan $(\alpha)=0,05$ dengan derajat kebebasan 42 adalah 2,02 maka $\mathrm{T}_{\text {hitung }}>\mathrm{T}_{\text {tabel }}$ maka Ho ditolak Ha diterima, ini berarti terdapat pengaruh yang siginifikan dari penggunaan model pembelajaran Learning Cycle terhadap kemampuan divergen siswa. Berdasarkan hasil pengujian hipotesis tersebut, maka dapat disimpulkan bahwa model pembelajaran Learning Cycle berpengaruh positif terhadap kemampuan divergen siswa.

\section{Pembahasan}

Hasil analisis dari penelitian ini menujukkan bahwa penggunaan model pembelajaran Learning Cycle memberikan pengaruh yang baik terhadap hasil belajar siswa. Hal ini dibuktikan dengan kemampuan divergen siswa pada kelas eksperimen menggunakan model pembelajaran Learning Cycle dan kelas kontrol menggunakan model pembelajaran konvensional pada hasil evaluasi speaking class.

Hal ini juga dibuktikan pada hasil rata-rata yang diperoleh dikelas eksperimen lebih besar dibandingkan kelas kontrol, yakni rata-rata 81,16 dan simpangan baku (stndar deviasi) 100,9 menggunakan model pembelajaran Learning Cycle, sedangkan hasil rata-rata yang diperoleh dikelas kontrol yaitu 62,0 dan simpangan baku (standar deviasi) 99,2 menggunakan model pembelajaran Konvensional.

Terbukti dari hasil penelitian yang menunjukkan nilai rata-rata kemampuan menyampaikan berkomunikasi setelah menggunakan model pembelajaran learning cycle, lebih tinggi yakni sebesar 81,16 (katagori baik) daripada nilai ratarata kemampuan berkomunikasi kelas kontrol yaitu 62,0 (katagori cukup).

Sudah sewajarnya kemampuan berkomunikasi meningkat. Hal tersebut dikarenakan model pembelajaran learning cycle yang digunakan sebelum proses pembelajaran meningkatkan minat siswa terlebih dahulu dengan cara bertanya 
jawab dan memberikan gambaran kasus untuk diselesaikan ( brainstorming ) untuk diidentifikasi sehingga siswa mampu menggambarkan objek, imaji serta diksi dan solusi yang digunakan untuk menyelesaikan evaluasi analisis yang telah diberikan.

Hal tersebut sejalan dengan pendapat Anthony W. Lorbach bahwa learning cycle merupakan salah satu cara yang menarik untuk meningkatkan minat siswa tentang materi speaking class dengan fase-fase yang diterapkan yang diterapkan dalam proses pembelajarannya yaitu engage,(mengajak/pembangkitan minat), ekplore (menyelidiki), eksplain (menjelaskan), ekstend (memperluas), dan evaluate (menilai).

\section{SIMPULAN DAN SARAN}

Peneliti sudah melaksanakan penelitian di tingkat Sekolah Menengah Atas, dan menghitung hasil data yang telah diperoleh sehingga dapat disimpulkan bahwa berdasarkan perhitungan uji hipotesis yang mengacu pada ketentuan pengambilan keputusan uji hipotesis, dikatakan bahwa Ho ditolak dan $\mathrm{Ha}$ diterima. Jadi dapat disimpulkan bahwa terdapat perbedaan yang signifikan kemampuan divergen antara siswa yang mengikuti pembelajaran dengan model pembelajaran Learning Cycle dengan siswa yang mengikuti pembelajaran yang menggunakan model pembelajaran Konvensional pada siswa kelas XI MA Nhurush Sholeh dan MA Miskyatul Ulum Kecamatan Mangaran Situbondo tahun pelajaran 2017/2018 dengan $\mathrm{T}_{\text {hitung }}>\mathrm{T}_{\text {tabel }}$ yaitu 6,67>2,02 pada taraf siginifikan $\alpha(0,05)$.

\section{DAFTAR PUSTAKA}

Adnyana. Putra. 2011. Model Siklus Belajar (Learning Cycle). Tersedia pada http://putradnyanagede.blogspot.com/2011/06/model-siklus-belajar-learningcycle.html. (diakses pada tanggal 21 Agustus 2017).

Candiasa, I M. 2004. Statistik Multivariat disertai Aplikasi dengan SPSS. Buku ajar (tidak diterbitkan). IKIP Negeri Singaraja.

Emzir. 2013. Metode Penelitian: Kuantitatif dan Kualitatif. Jakarta: Rajawali Persada. 
Isman.2012. Metode Brainstorming (Sumbang Saran). Tersedia pada http://www.Guru kelas.com/2012/08/ metode-brainstorming-sumbang-saran. html. (diakses pada tanggal 21 Agustus 2017).

Isriani, Hardini. 2011. Strategi Pembelajaran Terpadu (Teori, Konsep dan Implementasi). Pekalongan: Familia.

Ngalim, Purwanto dan Djeniah. 1997. Metodologi Pengajaran Bahasa Indonesia di Sekolah Dasar. Jakarta:Rosda Jayaputra.

Rawlinson, J.G. 1976. Berpikir Kreatif dan Brainstorming. Jakarta: Kencana

Riyanto, Yatim. 2008. Paradigma Baru Pembelajaran. Jakarta:Kencana. Sanjaya, Wena. 2006. Strategi Pembelajaran Berorientasi Standar Proses Pendidikan. Jakarta:Prenada Media.

Saputra. 2011. Penerapan Model Pembelajaran Learning Cycle 5e Bebantuan Lembar Kerja Siswa Terstruktur untuk Meningkatkan Hasil Belajar Matematika Siswa Kelas IVb SD N 1 Banyuning. Skripsi (tidak diterbitkan). Singaraja: Universitas Pendidikan Ganesha.

Sugiyono. 2014. Metode Penelitian Kuantitatif, Kualitatif, dan R\&D. Bandung. Alfabeta 